Marquette University

e-Publications@Marquette

College of Education Faculty Research and

Publications

Education, College of

$10-1-2017$

\title{
A Rationale for Requiring Philosophy of Education in Preservice Teacher Programs
}

Jeffrey LaBelle

Marquette University, jeffrey.labelle@marquette.edu

Gabrielle Belknap

Marquette University, gabrielle.belknap@marquette.edu

Accepted version. Journal of Education, Vol. 197, No. 3 (October 1, 2017): 51-60. DOI. (C) 2017

SAGE Publications. Used with permission. 
Marquette University

\section{e-Publications@Marquette}

\section{Education Faculty Research and Publications/College of Education}

This paper is NOT THE PUBLISHED VERSION; but the author's final, peer-reviewed manuscript.

The published version may be accessed by following the link in the citation below.

Journal of Education, Vol. 197, No. 3 (2017): 51-60. DOI. This article is (C) SAGE Publications and permission has been granted for this version to appear in e-Publications@Marquette. SAGE Publications does not grant permission for this article to be further copied/distributed or hosted elsewhere without the express permission from SAGE Publications.

\section{Contents}

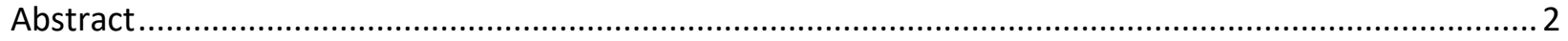

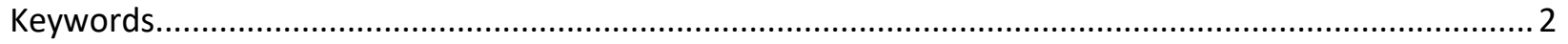

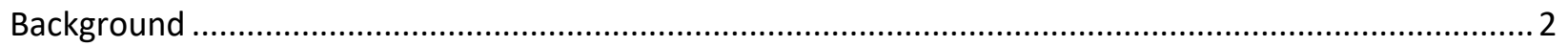

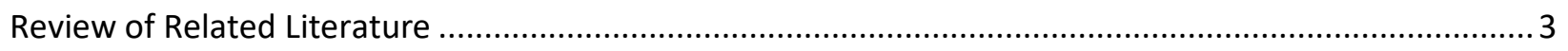

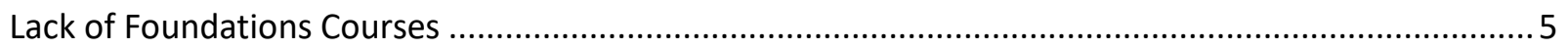

Variation in Content and Scope of Foundations Courses ............................................................. 5

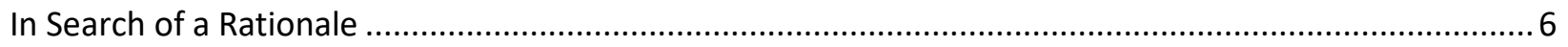

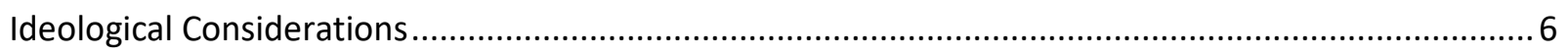

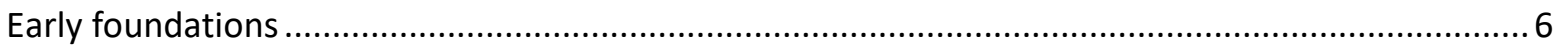

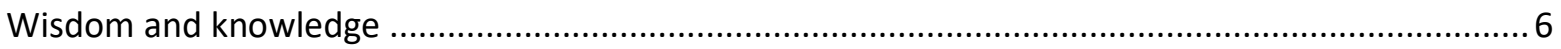

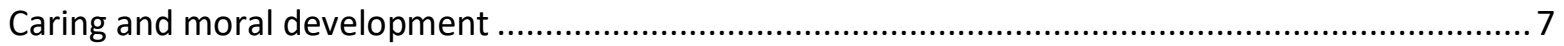

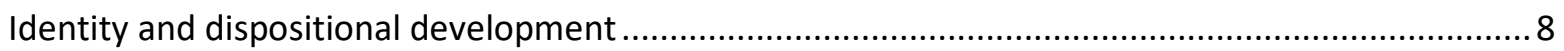

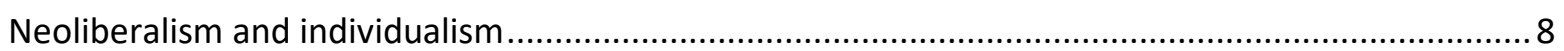

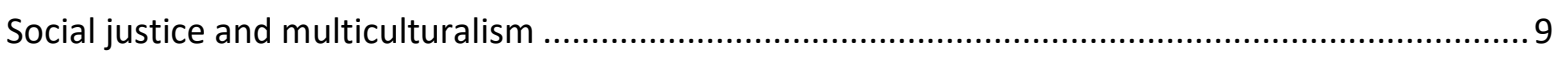

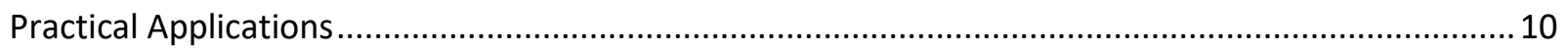

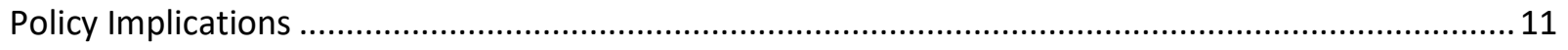

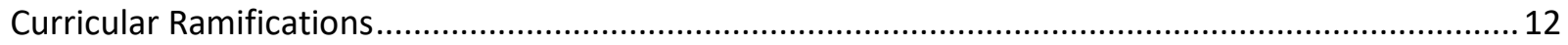

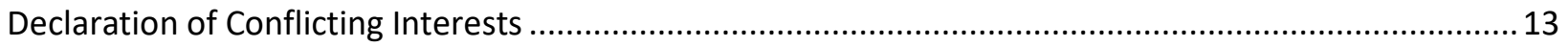




\title{
A Rationale for Requiring Philosophy of Education in Preservice Teacher Programs
}

\author{
Jeffrey T. LaBelle \\ Marquette University, Milwaukee, WI \\ Gabrielle Belknap \\ Marquette University, Milwaukee, WI
}

\begin{abstract}
To develop a rationale for requiring a free-standing philosophy of education course in preservice teacher programs, the researchers reviewed prior literature to construct a framework to establish such a requirement. A review of required course content in non-Catholic (private and public) colleges and universities with preservice teacher programs in five Midwestern states in the United States revealed that most do not require such a course, hence the need for programs to reconsider how licensure candidates develop their teaching philosophies and review program articulation and course content. This study proposes a fourfold theoretical rationale for requiring philosophy of education of preservice teachers.
\end{abstract}

\section{Keywords}

teacher education, policy, curriculum, higher education, social justice

\section{Background}

The value and need for studying philosophy of education has long been established by multiple philosophers and theorists across the past century from Dewey (1916) to Zeichner (2012).

Unfortunately, it would appear that a trend has occurred in many non-Catholic and non-religious institutions of higher education (IHEs) in various states to eliminate requiring preservice teachers to enroll in a course in the philosophy of education. In this research study, we reviewed some selected theories that promote the study of the philosophy of education. Next, we investigated self-reported course offerings of philosophy of education in preservice teacher education programs in a five-state region. Then, we explored potential root causes of such a trend in the available literature. Finally, we established a theoretical rationale for the value and purpose of requiring courses in philosophy of education in preservice teacher programs. Our findings suggest that programs omitting such a requirement may lack both the ideological and practical grounding that preservice teachers urgently need to link theory with practice as they enter the education profession. 
Reflecting upon our observation and teaching of philosophy of education classes for the past 10 years, we sought to determine the perceived purpose and value of such a course as a requirement for preservice teachers. As a point of departure, we note here the course description and purpose statement in the syllabi from our own sections of philosophy of education at a Midwestern Catholic university: "Principles and methods of various classical and contemporary philosophies and their implications and applications in education. Attention to professional ethics and students' development of their own philosophies of education" (Marquette University Undergraduate Bulletin, 2017-2018). Because of the rather generalized nature of such course descriptions, we designed a more specific purpose statement for this course to include in the syllabus and to help direct preservice teachers to envision how this course might be incorporated into their development as professional educators:

This course is designed to provide each student with an introduction to the processes and methods of educational philosophy, as well as to guide the teacher candidate in the development of a personal philosophy of education. To that end, this course will foster critical reflection and dialogue about educational philosophy representing different historical and cultural perspectives. The ultimate goal of this course is to foster a thoughtful, reflective approach to the practical development of curriculum, teaching methodology, and classroom management based upon one's personal values and beliefs. (LaBelle, 2015)

Another element to help direct preservice teachers to grasp the purpose of a philosophy of education course is one state standard that is cited in the syllabus and based on one state's version of the Interstate Teachers Assessment and Support Consortium (InTASC) standards for teacher preparation:

Standard 9: Teachers are able to evaluate themselves. The teacher is a reflective practitioner who continually evaluates the effects of his or her choices and actions on pupils, parents, professionals in the learning community and others and who actively seeks out opportunities to grow professionally. (Wisconsin State Department of Public Instruction, 2013)

These additional descriptions of the purpose of the course and the state standard serve to ground the focus of this phase of the preservice teacher program as well as direct the individual candidate toward knowledge, dispositions, and performances as noted in the state standards which will benefit them as professional educators. InTASC, a project of the Council of Chief State School Officers, has already provided a lengthy discussion of these in its 2011 document "Model Core Teaching Standards: A Resource for State Dialogue." More recently, the Council for the Accreditation of Educator Preparation (CAEP, 2013) fully endorsed these same InTASC standards in one of its own accreditation standards:

Standard 1 endorses the Interstate Teacher and Support Consortium (InTASC) teacher standards in their entirety, and the performances, knowledge and dispositions that are extensions of those standards contain literally scores of references to cultural competence, individual differences, creativity and innovation and working with families and communities. (p. 21)

\section{Review of Related Literature}

We interpret and analyze the literature in this review from a critical pedagogical framework. Essential to that framework is an epistemology that reads the world from a historically situated and culturally contextualized perspective. In short, this epistemology interprets the truth critically from the marginalized periphery rather than the privileged center and is grounded in the lived historical and 
cultural experiences of the knower who lives on the periphery. In turn, this epistemology leads to not only critical consciousness but also transformative practice which further fosters personal and social transformation. Freire $(1970,2001)$ labeled this process conscientization, an epistemological development in the individual inherently linked to both consciousness and praxis with ethical, social, and political implications. In addition, such an epistemology guides ethical behavior and moral development that links consciousness with transformative action grounded in a philosophy of the human person as unfinished and free to act on values which reflect freedom, civic courage, and democracy.

In reviewing the available literature regarding philosophy of education courses across the United States to determine where, when, and how often such courses are required, we found that many undergraduate preservice teacher preparation programs at Catholic colleges and universities in the United States require candidates to take courses in philosophy (Mucci \& Cranston-Gingras, 2011). Among these, some institutions include a free-standing philosophy of education course as an essential part of their preservice teacher requirements. In reviewing the motivations and purposes for requiring a separate course in the philosophy of education, one finds great variation. For example, Gosselin (2007) emphasized the importance of philosophy of education courses for preservice teachers because "they typically do not understand how philosophy of education fits into the grand narrative of philosophy as a discipline" (p. 42). On the contrary, Mucci and Cranston-Gingras (2011) made the case for such courses by asserting that "philosophy courses pertaining to philosophy of education allow preservice teachers to begin to examine their own goals for teaching and how those goals will be accomplished through specific teaching methods" (p. 386). Regardless of the purported reasons for requiring preservice teachers to take courses in the philosophy of education, it is quite common for Catholic IHEs to seek to develop critical or reflective thinking skills throughout their preservice teacher programs.

After reviewing the websites of all of the non-Catholic 4-year teacher certification institutions across a five-state Midwestern region (Illinois, Indiana, Michigan, Ohio, and Wisconsin; see Tables 1 and 2), we concluded that a vast majority do not require a free-standing philosophy of education course for preservice teachers. In search of an explanation for such a trend, we reviewed the available literature that has investigated and discussed the ideology and reality of foundations courses in teacher preparation programs in general.

Table 1. Number of Public and Non-Religious IHEs Requiring Philosophy of Education by State.

Table I. Number of Public and Non-Religious IHEs Requiring Philosophy of Education by State.

\begin{tabular}{|c|c|c|c|c|c|}
\hline State & $\begin{array}{c}\text { Number of } \\
\text { public and } \\
\text { non-religious } \\
\text { IHEs }\end{array}$ & $\begin{array}{c}\text { Number of lHEs that } \\
\text { offer this course as an } \\
\text { elective or foundation } \\
\text { choice }\end{array}$ & $\begin{array}{l}\text { Number of lHEs that } \\
\text { require this course for } \\
\text { teacher certification }\end{array}$ & $\begin{array}{l}\text { Number of tHEs that } \\
\text { require a course } \\
\text { which has embedded } \\
\text { philosophy of } \\
\text { education for teacher } \\
\text { certification }\end{array}$ & $\begin{array}{l}\text { Number of lHEs that } \\
\text { do not require this } \\
\text { course for teacher } \\
\text { certification }\end{array}$ \\
\hline Illinois & 28 & $7(25 \%)$ & $14(50 \%)$ & 0 & $7(25 \%)$ \\
\hline Michigan & 13 & 0 & 0 & 0 & $13(100 \%)$ \\
\hline Ohio & 22 & I $(0.45 \%)$ & 0 & $3(13.6 \%)$ & $18(81.8 \%)$ \\
\hline Wisconsin & 10 & $2(20 \%)$ & 0 & 0 & $8(80 \%)$ \\
\hline
\end{tabular}

Noes. $\mathrm{IHE}=$ indtitutions of higher education.

Table 2. Number of Religious IHEs Requiring Philosophy of Education by State. 
Table 2. Number of Religious IHEs Requiring Philosophy of Education by State.

\begin{tabular}{|c|c|c|c|c|c|}
\hline State & $\begin{array}{l}\text { Number of } \\
\text { rellgious IHEs }\end{array}$ & $\begin{array}{c}\text { Number of IHEs that } \\
\text { offer this course as an } \\
\text { elective or foundation } \\
\text { choice }\end{array}$ & $\begin{array}{l}\text { Number of IHEs that } \\
\text { require this course for } \\
\text { teacher certification }\end{array}$ & $\begin{array}{l}\text { Number of IHEs that } \\
\text { require a course } \\
\text { which has embedded } \\
\text { philosophy of education } \\
\text { for teacher certification }\end{array}$ & $\begin{array}{l}\text { Number of IHEs that do } \\
\text { not require this course } \\
\text { for teacher certification }\end{array}$ \\
\hline Illinois & 17 & 0 & 7 (4I.1\%) & 0 & $10(58 \%)$ \\
\hline Indiana & 15 & 0 & $1(0.6 \%)$ & $4(26,6 \%)$ & $10(66.6 \%)$ \\
\hline Michigan & 13 & $1(7.6 \%)$ & $2(15.3 \%)$ & $5(38.4 \%)$ & $5(38.4 \%)$ \\
\hline Ohio & 18 & $1(5.5 \%)$ & $3(16.6 \%)$ & $7(38.8 \%)$ & $7(38.8 \%)$ \\
\hline Wisconsin & 12 & $4(25 \%)$ & $2(16.6 \%)$ & 0 & $6(50 \%)$ \\
\hline
\end{tabular}

Nose. $\mathrm{IHE}=$ instioutions of higher education.

\section{Lack of Foundations Courses}

Upon close examination of the literature, one might surmise that a trend has occurred to intentionally reduce the number and limit the content of foundations courses in preservice teacher programs. The question arises as to whether these conclusions are mere conjectures or are indeed based on an actual review of program requirements in teacher education across the United States. For example, ThayerBacon (2011) observed that "educational foundations programs are almost entirely gone from colleges of education" (p. 135). Bullough and Kridel (2011) appeared to agree that "something very important, foundational, relevant, and profoundly philosophical is increasingly missing from teacher education programs" (p. 26). Unfortunately, Carlson (2011) also asserted,

As the dominant discourse in state educational policy has sought to reorganize teacher "training" as K-12 education has been reorganized, to bring them into "alignment" as they say, the role of philosophy, and indeed what still passes for the Foundations of Education in teacher preparation programs, will remain tenuous at best. (p. 11)

Furthermore, it would appear that changes in the style of philosophy has added to the changed emphasis of philosophy of education courses. Bullough and Kridel (2011) noted that ". . . increasingly the lines separating philosophical inquiry from other kinds of professional activity are blurred and much good philosophy is done by academics who are social scientists first and philosophers second" (p. 26). Such blurring might lead to co-opting essential values of one's philosophy of education for more business-oriented models of teaching and learning. To that point, Giroux (2011) claimed this is a trend to base public school curriculum and teaching methodology on a market-driven analysis, thus minimizing the truly public nature of education in favor of privatization through free enterprise models. In short, due to the perceived reduction of and apparent changes in content of philosophy of education courses in preservice teacher programs, a more robust rationale for requiring these courses is needed.

\section{Variation in Content and Scope of Foundations Courses}

In addition to the changes noted in U.S. philosophy of education, Theobald and Tanabe (2011) accurately recalled that "before the ascendancy of psychology to the status of distinct discipline within American universities ... teacher preparation leaned much more heavily on education philosophy than it currently does" (p. 39). Furthermore, Carlson (2011) pointed out that, in part due to the "critical, antioppressive, and socially reconstructionist" nature of the approaches utilized by foundational faculty, "... we are witnessing an intensification of efforts by the neoliberal and neoconservative state to bring the 'applied' university faculty, and particularly those in teacher education, under much greater control" (p. 21). All of these insights, observations, and suggestions about the content and scope of foundation 
courses point to the need for a more radical rationale for promoting philosophy of education as an essential component of preservice teacher preparation.

\section{In Search of a Rationale}

Our careful, critical review of literature regarding the rationale for requiring preservice teachers to take a course in the philosophy of education revealed multiple thematic approaches to the issue: (a) ideological considerations, (b) practical applications, (c) policy implications, and (d) curricular ramifications. What we found lacking in our review of previous research was a cogent, unified rationale for requiring preservice teachers to take a course in the philosophy of education. We seek to generate such a rationale by critically examining this issue in the light of these four thematic approaches and the ways in which they interrelate. Because ideological considerations often fuel the arguments in favor of a case, we first focus on ideological factors in this review of potential rationales for philosophy of education as a course of study for preservice teachers.

\section{Ideological Considerations}

Lacking a firm philosophical foundation, teachers might be coerced into following the whims of the latest trends in pedagogical practices as reflected in the newest textbook editions and technological advancements. Indeed, a preservice teacher's ideological grounding is essential to critically analyze methods and materials in actual classroom practice. To examine the impact of these concerns, let us first consider ideologies from their early foundations in U.S. education.

\section{Early foundations}

Beginning with the renowned philosopher of education, John Dewey (1916), we find clear and distinct ideas about the ideological grounding for a philosophical approach to education: "The educational point of view enables one to envisage the philosophic problems where they arise and thrive, where they are at home, and where acceptance or rejection makes a difference in practice" (p. 383). Indeed, throughout the history of U.S. education, either implicitly or explicitly, particular philosophies have shaped every aspect of educational reform. In their reflection on this matter, Bullough and Kridel (2011) made this quite evident:

Then, as now, the case had to be made that social philosophy was profoundly important and should infuse virtually all educational practice. Slowly they came to realize that determining educational aims and means led to rich, lengthy discussions about what type of community they wished to build for themselves and for their students. (p. 33)

Hence, a philosophy of education establishes the necessary conditions for educational practice: at the very least, educational theory informs classroom practice especially in regard to its aims, values, and purpose. To this end, Freire (2001) claimed that, to develop a truly empowering, transformative pedagogy, a reciprocal, dialogical relationship between theory and practice, enlightened through critical reflection and grounded in an epistemological curiosity, must exist.

\section{Wisdom and knowledge}

At the heart of the matter is the question of how to teach wisdom as well as how to acquire knowledge. Defining these two terms is particularly challenging and furthermore quite informative regarding one's operative philosophy of education. Sternberg (2013) took up the issue of the elusiveness of grasping the concept of wisdom when he intimated, "But even more important, academic smarts also are only 
weakly correlated with wisdom" (p. 40). He went on to define wisdom ". . .as the seeking of a common good-over the long and short terms-by balancing one's own interests, those of others', and higher interests through the infusion of positive ethical values" (p. 40). Nevertheless, Sternberg claimed that such positive ethical values of themselves do not establish a sufficient condition for wisdom.

So, just how would one go about teaching wisdom? Here, the key distinction must be made between the use of knowledge and its mere acquisition. As Sternberg (2013) elucidated, "Teaching students to think wisely would mean placing far greater emphasis on the uses to which knowledge is placed-for good or for bad-not just on the acquisition of knowledge" (p. 47). Essential to the role of the teacher of wisdom is assisting or guiding students toward their own ethical position, rather than serving as agents of moral education or imposers of a particular morality. Sternberg (2013) consequently concluded, "Wise thinking can be taught in the context of almost any discipline. . .more than anything else, teaching for wisdom involves role modeling" (p. 47).

Several years earlier, Sleeter (2008) had discussed a similar concern but in regard to teacher preparation and the danger of disconnecting candidates from the communities or contexts in which they will serve. Hence, she advocated for candidates "being taught by teachers who know how to engage them in rigorous and meaningful intellectual work [rather] than being taught to follow directions and regurgitate rote learning" (p. 1954). Implicitly, Sleeter's commentary underscores an important distinction between fostering true wisdom and merely acquiring knowledge, what Freire $(1970,2001)$ would consider banking education.

\section{Caring and moral development}

Another essential ideological consideration is the concept of caring in the teaching profession as well as the moral development of the learner. Pedagogical considerations of this sort are necessarily part and parcel of one's philosophy of education. Indeed, many have promoted and encouraged a nurturing, caring approach to teaching. Theobald and Tanabe (2011) insisted, "Noted educational researchers have argued eloquently for the need for 'nurturing pedagogy' (John Goodlad, 1997) or for 'caring' as a critical part of pedagogy (Nel Noddings, 1984)" (p. 40).

In addition, the preparation and moral character of the educator plays an important part in carrying out this ethical mandate for nurturing and caring. Regarding good preparation, Sleeter (2008) elucidated, "Well-prepared teachers are critically important to the well-being of children and youth as they become adults, and particularly for those in underserved communities, for whom an excellent education can be a lifeline" (p. 1955). This same quality of preparation has an implicit moral dimension with social ramifications. Sleeter (2008) further illustrated,

Preparing teachers well means engaging actively with those communities, breathing life into democracy as a moral purpose of education. In the US, doing so is not only a moral imperative, but may, in the long run, be necessary to the survival of teacher education. (p. 1955)

Clearly, then, ideological considerations must take into account a nurturing, caring approach, which, in turn, necessarily leads to the development of a moral and social responsibility to educate for the wellbeing of both the individual and a democratic society. 
Identity and dispositional development

In U.S. culture, individuality and personal freedom are highly regarded values. "The individualistic assumptions about the human condition that underlie all institutions in American society have yielded that 'hyper-individualistic' culture that Walzer and others have described" (Theobald \& Tanabe, 2011, p. 36). These values impact the way each person, including preservice teachers, perceives his or her individual and social identities. Identity, as we conceptualize it, is shaped by "our understanding of who we are and who we think other people are" (Danielewicz, 2001, p. 10). Varghese, Morgan, Johnston, and Johnson (2005) contend that the process of identity development entails paying attention to "identityin-discourse" as well as "identity-in-practice." Identity-in-discourse emphasizes that "identity is constructed, maintained and negotiated to a significant extent through language and discourse" (Varghese et al., 2005, p. 23). Identity-in-practice centers on the ways in which one becomes aware of one's self through experience.

In essence, the identity development of young or emerging adult preservice teachers forms the grounding of their attitudinal or dispositional development. At the very least, an interplay between these two aspects of their development exists. Most assuredly, the high regard Americans hold for individuality and personal freedom has a profound impact on the development of the individual who pursues teacher licensure.

Actual classroom experience, interaction with students, and social discourse with other educators together help shape the identity of the preservice teacher as an educator (Greene, 1973; Roland Martin, 1992). This discourse between the individual preservice teacher and his or her context serves as the grounding of attitudinal or dispositional development. Danielewicz (2001) explained, "Discourse, which is manifested through language, consists of a system of beliefs, attitudes, and values that exist within social and cultural practices. Engaging in these language practices ... shapes an individual's identity" ( $p$. 11). Ultimately, all of the elements of the cultural context or ethos of teaching and learning assist in the formation of one's individual identity as an educator.

Finally, a much broader conceptualization of the educator is essential to grasp the identity formation of these preservice teachers. Trent (2013) pointed to the importance of this effort among teacher educators when he asserted,

...the identity work of these teacher educators underscores that the transition from teacher to teacher educator is shaped partly by situated experiences of learning and teaching within particular institutional settings. . .as well as broader societal discourses of teaching and learning that differ across educational jurisdictions. (p. 274)

To move preservice teachers toward this goal of situating their learning and teaching in experiential settings, teacher education programs must articulate the relationship between theory and practice as well as inculcate appropriate dispositional development to foster such integration among the licensure candidates (LaBelle \& Belknap, 2016).

Neoliberalism and individualism

In looking at education from historical and economic perspectives, one notes an ideological shift toward neoliberalism and individualism as dominant paradigms when addressing systemic school reform. This can be seen in various attempts to improve learning outcomes through privatized investment as well as numerous ventures such as charter schools, magnet schools, choice schools, and open district 
enrollment efforts. In essence, U.S. individualism and neoliberalism have reframed the dominant paradigm of education in this country to emphasize testing, quantifiable data, and accountability (Giroux, 2011; Noddings, 2015). Theobald and Tanabe (2011) noted, "Philosophers of considerable distinction, from John Rawls to Charles Taylor, have spent time and energy trying to sort through the vast array of historical circumstances that have come together to create America's brand of individualism" (p. 36). This unique interpretation of individualism is the basis of an important ideological consideration of the value and effectiveness of a neoliberal approach to improving U.S. schools.

Sleeter (2008) made this concern about individualism quite clear when she insisted, "Teacher education now finds itself under assault in the context of neoliberal pressures on education and society more broadly" (p. 1952). Then, she went on to delineate three such pressures on U.S. teacher education:

(1) away from explicit multicultural, equity oriented teacher preparation, and toward preparing teachers as technicians to implement measures school districts are taking to raise student test scores; (2) away from defining teacher quality in terms of professional knowledge, and toward defining it terms testable content knowledge; and (3) toward shortening university-based teacher education or by-passing it altogether. (p. 1952)

The problem with the first pressure, to train teachers as if they were technicians, is that such an approach ". . .reinforces an ideological shift away from education as preparation for democratic participation, firmly nailing down education as work preparation" (Sleeter, 2008, p. 1952). Furthermore, it sustains and perpetuates the limited ways in which issues of equity are debated, often reducing them to focus upon achievement gap analysis based on standardized test scores alone (Sleeter, 2008).

In this fashion, great pressure is also exerted to center school reform discourse on neoliberal, economic efficiencies rather than zeroing in on the injustices of the endemic as well as systemic economic inequality. In turn, this type of pressure fosters an approach to teacher education which minimizes or downsizes professional development by “. . . defining highly qualified teachers in terms of tested subject-matter knowledge" (Sleeter, 2008, p. 1953), even to the point of questioning the need for college-based preservice teacher education. In fact, many states, in attempts to reduce taxes and stave off the rising cost of public services, have ". . .reduced public expenditures on higher education" (Sleeter, 2008, p. 1954). This neoliberal economic ideology in turn has even forced IHEs to shorten programs such as teacher education for financial efficiency. Swain (2013) contended that we need to reframe ". . these neoliberal measures as punitive policies that are destroying public education" ( $p$. 129). Swain further insisted that educational research needs to not be "mired in the bog of scientism," but ought to include "the lived stories and experiences of those in our schools" (p. 129).

Social justice and multiculturalism

Pressures to perform, teach to the test, and emphasize technique are taking away from content and context approaches to teaching that would better address social injustices and multiculturalism in U.S. schools today. Swain (2013) claimed,

Technocratic methods are replacing courses on content and context, instead of these two existing in a space of both/and. Fear of punishment from without-and within-ensures that teachers are being taught to teach to the test; the future of schools and one's job depends upon it. (p. 121) 
Indeed, pressures to keep up to date technologically as well as to be accountable for students' success in achieving grade level as demonstrated on standardized tests have derailed efforts and time dedicated to issues of inclusion and social justice in the classroom. Sleeter (2008) saw the solution in emphasizing field placements and social contexts:

The best way for US teacher education to move forward is to shift the centre of gravity from the university to the field and from preparing teachers for "generic" children to preparing them well for the most diverse and challenging contexts. This entails learning to collaborate not only with schools, but also with historically underserved communities. (p. 1954)

Even so, the issues of social justice and multiculturalism must be addressed in the formation of future educators, especially in their formal education at the college level. Swain (2013) referred to Teachers College as a historical model for such an approach,

Through a diverse and eclectic program of study that ranged from Plato to Marx, student teachers were to consider, engage, and contribute to the reformation of social injustices. . .teachers were to be actively responsible for shaping a collective future. (p. 124)

In addition to the challenges of training preservice teachers, contemporary media and popular culture continue to malign the profession, thus exacerbating the fear of failure on the part of licensure candidates (Swain, 2013). In fact, Labaree (2004) asserted that teaching is often misunderstood as an "enormously difficult job that looks easy" (p. 39).

\section{Practical Applications}

Without establishing some clarity of their own philosophical perspective, preservice teachers might easily resort to implementing teaching methodologies based on factors contrary to their own beliefs and values. These could include planning curriculum solely based on the results on achievement tests or on classroom management issues. Such pragmatic or behaviorist philosophies might actually conflict with the classroom teacher's own philosophy of education. It is one matter to study the content and concepts of educational theorists and yet another to critically analyze, question, and implement them in classroom practice. In fact, as McDonald, Kazemi, and Kavanagh (2013) warned, a danger exists in unduly mechanizing the nature of preservice teacher preparation to base it solely on techniques, practices, and set methodologies. Because of this tendency toward superficial treatment of pedagogical theories, this study will now take a look at the practical application of such philosophies.

When viewed in regard to their practical applications, philosophy of education and foundational courses are often deemphasized and seen as less helpful due to the practicality of "nuts and bolts" methods courses and the immediate results they yield. First, let us reflect on the deemphasis that has occurred. Citing Kerr et al. (2011), Swain (2013) pointed out “. . . part of the reason schools of education have deemphasized history and philosophy courses in teacher curricula is because students believe these courses to be less helpful than methods courses" (p. 123). Of course, it is rather difficult to measure student beliefs, much more difficult to alter them regarding the importance of certain courses of study.

This leads us to shift our attention, then, to the practicality or utility of philosophy of education courses. Earlier in his study, Swain (2013) discussed the importance of a "nuts and bolts" approach to teacher education as an increased focus during the previous decade. He claimed, "How to teach is replacing why we teach" (p. 122). Swain further stressed the value of foundations courses posing philosophical 
questions of great importance such as "What is the purpose of education? Why do we educate? What does education do? Who are we educating? But more important, who are we to educate?" (p. 122). Unfortunately, as Zeichner (2012) pointed out, "Walsh and Jacobs (2007) criticize elements of teacher education that they do not see as immediately useful to new teachers and use foundations courses as the example of courses that are 'nonessential'" (p. 379). Zeichner (2012) proposed a counternarrative to this critique by asserting that "teachers should be evaluated on how well they know and do them rather than on the completion of certain required courses" (p. 377).

Finally, let us examine some additional practical applications that underscore the value or purpose of requiring philosophy of education for preservice teachers. For example, Thayer-Bacon (2011), in reflecting on her own teaching of courses such as the philosophy of education, concluded that foundational courses

... also help teachers in their efforts to become professionals, and treated by our society as professionals. . . They help teachers learn how to listen generously to parents, colleagues, and administrators, and seek to understand diverse positions on various educational issues, while also learning how to make their case and defend their positions, by being able to give good reasons and cite solid research to support their positions. (p. 137)

Her position is quite convincing that requiring preservice teachers to take philosophy of education, as well as other foundational courses, serves multiple practical purposes in sharp contrast to others who have seen them as impractical or non-essential. Thayer-Bacon (2011) went on to insist, "It has been my continuing position during my career in education that all teachers face philosophical issues on a daily basis" (p. 137).

\section{Policy Implications}

Without a sound philosophical foundation, teachers are susceptible to governmentally imposed requirements for content standards and pedagogical practices that devalue their ability to reason freely or think critically. Indeed, preservice teachers' ability to reflect philosophically about these issues is essential if they are going to face the demands of the profession and still be creative in their teaching styles. Let us first consider the policy implications from the perspective of governmental requirements.

To a certain extent, standardized testing is a necessary evil: on one hand, it can help assess the learning levels of the students; on the other, it can unduly stigmatize and even track the future career path of the students. Sternberg (2013) quite correctly pointed out the dangers of reading too much into the association of ability or achievement tests with success in careers and future goals because ". . to an unknown extent, our society manufactures this correlation by allowing primarily those who test at high levels to have access to the highest-paying and most prestigious jobs" (p. 46).

Regarding teaching authority, the imposition of more government requirements limits the freedom and opportunity of teachers to decide which content to include in their lesson plans and the timing and sequencing of the content. Policy makers, rather than educational professionals, have set up core standards which allow little room for flexibility for the individual classroom teacher. "In an age where teacher authority has been reduced by policymakers to the point where it can scarcely be said to exist, a substantive course in educational philosophy seems to be a kind of professional imperative" (Theobald \& Tanabe, 2011, pp. 41-42). These policy and governmental restraints directly impact the pedagogical practices of professional educators in the field. 
Much has been written about the No Child Left Behind Act (NCLB) and its impact on schools and teachers. An additional area of critique, however, is worth mentioning about the effect of NCLB on preservice teacher education. Carlson (2011) quite appropriately and succinctly observed, "Not only is NCLB 'dumbing down' the education many young people receive to a set of basic skills. . it is also having the effect of 'dumbing down' teacher education through a narrow emphasis upon technical pedagogical knowledge and performance outcomes" (p. 21). Of course, none of this is to deny the challenge that teacher education programs face in integrating theory and practice as well as the necessary reflection on these. In fact, Zeichner (2012) emphasized the need for a balance between theory and practice in developing educational policies when he described ". . . the task of developing a system. . .that is evidence-based, sustainable, and that does not ignore important aspects of good teaching" (p. 376). As one might observe in all of these pedagogical practices, an underlying presumption exists that discourages and even devalues critical thinking on the part of the classroom teacher. Let us now turn our attention to this ethical matter.

If, as Sleeter (2008) argued, we as a society expect our teachers to prepare students in work training, not in democratic participation, it is ironic that the shift away from philosophy of education will also be a disservice for career preparation. If teachers are to prepare students for an ever-changing world, they must be engaged in critical thinking and transformative experiences so that they are able to help their students learn to question, critically think about, and read their world (Freire, 1970, 2001).

Critical thinking skills are often part of the learning outcomes for all levels of students from kindergarten through college. It would only seem logical that preservice teachers would need to develop these same skills in themselves to teach them to others. Sternberg (2013) asserted, "If students don't learn how to think wisely and to become lifelong learners, their careers will be victims of the same planned obsolescence that characterizes so many of our household purchases" (p. 46). More specifically in regard to the future educator, Paul (1985) insisted, "The single most useful thing a teacher can do is to take at least one well-designed college course in critical thinking, in which the teacher's own thinking skills are analyzed and nurtured in a variety of ways" (p. 37). In spite of these best practices, many of the policy implications of standardized testing, common core content standards, and NCLB mandated reforms would appear to devalue any critical thinking on the part of the individual classroom teacher. Preservice teachers who study the philosophy of education have an excellent opportunity to critically reflect upon policy, theory, and classroom practice, that is, to question why certain methods, resources, and content are required so as to improve the quality of their teaching and enhance student learning. "If we want real change, if we want real educational reform, we need to do a better job of immersing teacher education students in the life-changing experience of philosophical contemplation" (Theobald \& Tanabe, 2011, p. 42). Such reflective thinking or philosophical contemplation necessarily leads to changes in the curriculum.

\section{Curricular Ramifications}

A teacher's vision or philosophy of education, or the lack of one, has definitive curricular ramifications. These entail the selection of one's teaching methodology as well as types of resources one uses. Implicit in such choices is a set of values that would best be grounded in an articulated philosophy of education. For example, perennial, multicultural, and critical philosophies all have different approaches to curriculum and instruction. However, to adopt and critique any philosophy, or implement a synthesis of philosophies, a teacher must have the background and contextual knowledge necessary to do so. 
A reflective teacher will have the capability to critically analyze choices of resourcing such as forms of technology to determine the suitability for his or her students. "Given the reality that educational technology alone may not be the answer to all our modern educational questions, the future of American education will depend on additional vigorous fields of study" (Theobald \& Tanabe, 2011, p. 38). Besides the thoughtful, critical selection of resources, the preservice teacher needs to be equipped to deal with a wide variety of learning styles, cultural styles, and language backgrounds. As Zeichner (2012) insightfully observed, "Another element that is not typically included in discussions of preparing teachers to enact high-leverage teaching practices is the development of teachers' cultural competence and ability to teach in culturally responsive ways" (p. 380). Even beyond these variations in culture and language, educators must have prudent judgment to adjust and fine-tune their curricula as perceived in their particular context. Zeichner (2012) warned of overemphasizing a one-size-fits-all approach when he insisted,

Finally, one danger we have to watch out for is the use of artifacts of teaching as scripts that undermine teachers' abilities to exercise their judgment and to adapt instruction to meet the constantly changing needs of their students and the different contexts of their work. (p. 379)

Ultimately, a teacher's role encompasses much more than the mastery of teaching techniques that are successful. The curriculum of a particular teacher must take into account the vision that he or she sees as their purpose for guiding, leading, and orchestrating the lesson plans, as well as the values and morals that support the chosen approach or theory. In conclusion, we turn to Zeichner (2012) who eloquently elucidated,

It is important for those engaged in making the teaching of core teaching practices a central focus in teacher preparation programs to situate their work in relation to a vision of the teacher's role so that they do not imply that all that is necessary in teacher education is the mastery of a set of teaching practices. (p. 380)

Hence, from a critical pedagogical perspective, the optimal way to promote such a teacher's role is the requiring of philosophy of education for all preservice teachers. To not do so denies teacher candidates the opportunity to develop a clearly articulated viewpoint which is based on their personal values and by which they can analyze and implement culturally responsive pedagogy suited to the context of the learners. We contend that it is not as important that teachers share a "best" philosophy so much as they be able to understand, critique, and implement one that expresses their own beliefs, values, and ethics.

\section{Declaration of Conflicting Interests}

The author(s) declared no potential conflicts of interest with respect to the research, authorship, and/or publication of this article.

\section{Funding}

The author(s) received no financial support for the research, authorship, and/or publication of this article. 


\section{References}

Bullough, R. V., Kridel, C. (2011). Lost soul: The eradication of philosophy from colleges of education. In Kinceloe, J. L., Hewitt, R. (Eds.), Regenerating the philosophy of education: What happened to soul (pp. 25-34). New York, NY: Peter Lang.

Carlson, D. (2011). Eyes of the education faculty: Derrida, philosophy, and teacher education in the postmodern university. In Kinceloe, J. L., Hewitt, R. (Eds.), Regenerating the philosophy of education: What happened to soul (pp. 11-24). New York, NY: Peter Lang.

Council for the Accreditation of Educator Preparation . (2013). CAEP 2013 standards for accreditation of educator preparation. Retrieved from http://caepnet.org/ /media/Files/caep/standards/caep-standards-one-pager061716.pdf?la=en

Danielewicz, J. (2001). Teaching selves: Identity, pedagogy, and teacher education. Albany: State University of New York Press.

Dewey, J. (1916). Democracy and education. New York, NY: Macmillan.

Freire, P. (1970). Pedagogy of the oppressed. New York, NY: Herder \& Herder.

Freire, P. (2001). Pedagogy of freedom: Ethics, democracy, and civic courage. Lanham, MD: Rowman \& Littlefield.

Giroux, H. A. (2011). Education and the crisis of public values: Challenging the assault on teachers, students, \& public education. New York, NY: Peter Lang.

Goodlad, J. I. (1997). In praise of education. New York, NY: Teachers College Press.

Gosselin, C. (2007). Philosophy and the role of teacher reflections on constructing gender. Educational Foundations, 21(3/4), 39-57.

Greene, M. (1973). Teacher as stranger: Educational philosophy for the modern age. Belmont, CA: Wadsworth Publishing.

Interstate Teachers Assessment and Support Consortium . (2011). Model core teaching standards: A resource for state dialogue. Retrieved fromhttp://www.ncate.org/ /media/Files/caep/accreditation-resources/intasc-teacherstandards.pdf Google Scholar

Labaree, D. F. (2004). The trouble with Ed Schools. New Haven, CT: Yale University Press.

LaBelle, J. (2015). Syllabus of philosophy of education (Unpublished document). Marquette University.

LaBelle, J., Belknap, G. (2016). Reflective journaling: Fostering dispositional development in preservice teachers. Reflective Practice, 17(2), 125-142.

McDonald, M., Kazemi, E., Kavanagh, S. (2013). Core practices and pedagogies of teacher education: A call for a common language and collective activity. Journal of Teacher Education, 64, 378-386. 
Mucci, A. M., Cranston-Gingras, A. (2011). A foundation for reflection and questioning: Philosophy course requirements in teacher education programs at selected Catholic colleges and universities. Catholic Education: A Journal of Inquiry and Practice, 14, 371-390.

Noddings, N. (1984). Caring: A feminine approach to ethics and moral education. Berkeley: University of California Press.

Noddings, N. (2015). Philosophy of education (4th ed.). Cambridge, MA: Westfield Press.

Paul, R. W. (1985). Bloom's taxonomy and critical thinking instruction. Educational Leadership, 42(8), 36-39.

Roland Martin, J . (1992). The schoolhome: Rethinking schools for changing families. Cambridge, MA: Harvard University Press.

Sleeter, C. (2008). Equity, democracy, and neoliberal assaults on teacher education. Teaching and Teacher Education, 24, 1947-1957.

Sternberg, R. J. (2013). Reform education: Teach wisdom and ethics. Phi Delta Kappan, 94(7), 4447.

Swain, A. (2013). The problem with "nuts and bolts": How the emphasis on "highly qualified professionals" is undermining education. Educational Studies: A Journal of the American Educational Studies Association, 49, 119-133.

Thayer-Bacon, B. J. (2011). Philosophy applied to education, revisited. In Kinceloe, J. L., Hewitt, R. (Eds.), Regenerating the philosophy of education: What happened to soul (pp. 127-140). New York, NY: Peter Lang.

Theobald, P., Tanabe, C. S. (2011). "It's just the way things are": The lamentable erosion of philosophy in teacher education. In Kinceloe, J. L., Hewitt, R. (Eds.), Regenerating the philosophy of education: What happened to soul (pp. 35-42). New York, NY: Peter Lang.

Trent, J. (2013). Becoming a teacher educator: The multiple boundary-crossing experiences of beginning teacher educators. Journal of Teacher Education, 64, 262-275.

Varghese, M., Morgan, B., Johnston, B., Johnson, K. (2005). Theorizing language teacher identity: Three perspectives and beyond. Journal of Language, Identity, and Education, 4, 21-44.

Walsh, K., Jacobs, S. (2007). Alternative Certification Isn't Alternative. Thomas B. Fordham Institute, Washington, DC. ERIC Document Reproduction Service No. ED498382.

Wisconsin State Department of Public Instruction . (2013). Teacher standards. Retrieved from https://dpi.wi.gov/

Zeichner, K. (2012). The turn once again toward practice-based teacher education. Journal of Teacher Education, 63, 376-382. 